
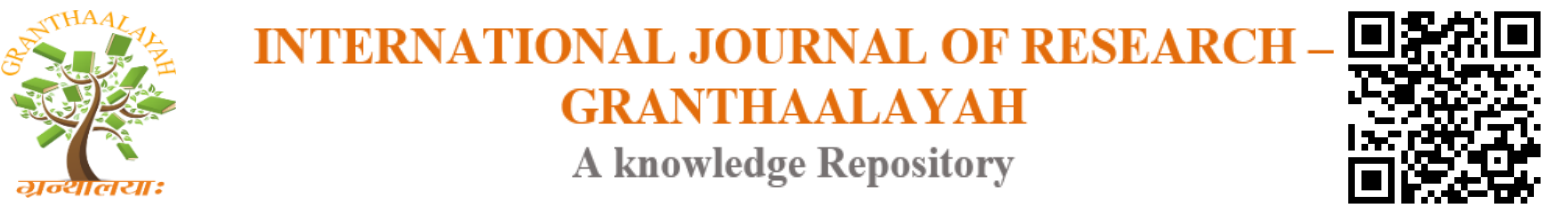

Science

\title{
CULTIVATION AND INGESTIBILITY OF ANGOLE PEAS (CAJANUS CAJAN) IN SAHEL GOAT IN NIGER
}

\author{
Ousseina Saidou *1, Ousseini Mahaman M. Mouctari ${ }^{1}$, Ridouane Ibrahim Barhiré ${ }^{1}$, Iro \\ Dan Guimbo ${ }^{2}$ \\ ${ }^{* 1}$ Département des Productions Animales, Faculté d'Agronomie, Université Abdou Moumouni, \\ Niamey/Niger, B.P.: 10960, Niamey, Niger \\ 2 Département Génie Rural, Eau et Forêts, Faculté d'Agronomie, Université Abdou Moumouni, \\ Niamey/Niger, B.P.: 10960, Niamey, Niger
}

\begin{abstract}
This study was conducted on the experimental site of the Faculty of Agriculture of Abdou Moumouni University of Niamey. Objective of the work is to study the culture of species Cajanus cajan while determining its applicability to the Sahel goat. Germination test was carried out in petri dishes. Experimental set-up consists of 360 pockets distributed in three blocks each containing four plots of which three plots received urea, three received the NPK, three others received the manure and in the end three were kept as controls. Time between the establishment of grain culture in petri dishes and first appearance of radicle is one day and the staggering of germination is four days. The emergence of seedlings was observed 7 days after sowing in pockets. The seeds have a germination rate of $67.14 \%$. At the first harvest, biomass production is $78.84 ; 89.42$ and $79.87 \mathrm{~kg}$ / ha respectively for plants treated with urea, NPK 15-15-15 and for plants treated with manure. Production of control plants is $50.45 \mathrm{~kg} / \mathrm{ha}$. Species Cajanus cajan has a higher appetence rate $(80 \%)$ compared to species Leuceuna lecocephala and Gliricidia sepium which have respectively 66.66 and $46.66 \%$.
\end{abstract}

Keywords: Culture; Ingestibility; Cajanus Cajan; Sahel Goat; Production.

Cite This Article: Ousseina Saidou, Ousseini Mahaman M. Mouctari, Ridouane Ibrahim Barhiré, and Iro Dan Guimbo. (2019). "CULTIVATION AND INGESTIBILITY OF ANGOLE PEAS (CAJANUS CAJAN) IN SAHEL GOAT IN NIGER.” International Journal of Research - Granthaalayah, 7(9), 30-38. https://doi.org/10.29121/granthaalayah.v7.i9.2019.554.

\section{Introduction}

Pastoral areas represent more than $38 \%$ of the territory of Sahelian countries such as Mali, Mauritania, Niger, Senegal, Chad and Burkina Faso (Bernard, 2013). Niger, by the diversity of its environments and its terroirs, constitutes an immense reservoir of various plants in particular of pastoral and fodder interest. Nevertheless, the agricultural pressure on the land leads to the reduction of pastoral areas which increases with demographic pressure (Cotula et al., 2009, 
Chauveau et al., 2006, Jouve, 2006, Cotula et al., 2006, Mathieu and Tabutin, 1996). The possibilities of development of forage crops and improvement of pastoral production are enormous but remain dependent on certain determinants such as seed production, management and land development, especially pastoral areas.

Niger is also facing a long dry period, which means that animal production, especially food, is dependent on natural resources. And they cannot meet the needs of animals. It is then necessary to find alternatives that will allow the flock to be able to feed the herds by producing a good quantity of fodder but also to reduce their dependence on the fodder production of natural pastures. One of the alternatives is the forage crop. And among the forage plants, the family of legumes is the most appreciated of the breeders. The species Cajanus cajan commonly known as pigeon pea (Jonhson and Raymond, 1964, quoted by Chrysostome et al., 1998), is one of the most used both in the intertropical zone and in West Africa. If the pigeon pea (Cajanus cajan) is very popular in West Africa by pastoralists for its tolerance to drought, its contribution to soil fertilization (Siambi et al., 1992), thanks to its richness in Nutrients, its adaptability to climatic conditions, its ability to regenerate soils and its multiple uses in humans and animals (Grâce et al., 2009), it is important to deepen its potential in terms of available forage. Thus, this study aims to evaluate the yield of foliar biomass of pigeon pea and to determine its ingestibility in goats of the Sahel.

\section{Materials and methods}

\section{Study Area}

The study was conducted at the experimental park of the Faculty of Agronomy of Abdou Moumouni University, located between coordinates $13^{\circ} 30$ 'north latitude and $2^{\circ} 08^{\prime}$ east longitude, at an altitude of $216 \mathrm{~m}$ (Mani, 2013).

The climate is Sahelian with high temperatures between April and June and low temperatures between December and January. Annual cumulative rainfall recorded from 2009 to 2018 varies from 350 to $650 \mathrm{~mm}$ with the exception of the year 2012 where there was a cumulative greater than $700 \mathrm{~mm}$.

\section{Biological and Technical Material}

The biological material consists of Cajanus cajan seeds produced during the 2017 rainy season. Other technical equipment including milestones for the measurement of plant heights, a pruner for the cutting of biomass, petri dishes and filter paper for the germination test were used.

\section{Methods}

\section{Germination Test}

The germination test was carried out in 7 petri dishes. The principle consisted of disinfecting pigeon pea seeds using an alcohol and moistening the filter papers before introducing about twenty seeds into each box. These petri dishes are then placed in an incubator at a temperature of $25^{\circ} \mathrm{C}$. Observations of germination began one day after the start of the experiment and continued until the third day after the last germination. The exit of the radicle is retained as a criterion of germination. Thus, the parameters used to evaluate germination are the germination time which reflects the time elapsed between sowing and the appearance of the radicle, the duration of 
germination or the average time of germination or staggering indicating the delay between the germination of the first seed and that of the last seed and germination rate.

\section{Assessment of Plant Emergence}

The evaluation test of the emergence was done on the experimental ground. It consists of sowing and then watering grains of pigeon pea in the plots daily until the end of the trial which lasted 15 days. Observations made every 2 days focused on seedling development.

\section{Establishment of the Cultivation of Cajanus Cajan}

The experiment took place at the experimental park of the Faculty of Agronomy of the Abdou Moumouni University in the winter season of 2018. The experimental device consists of three (3) blocks each of which is a repetition comprising four (4) plots or treatments, a set of 12 parcels of 4 meters by 5 , each parcel has 30 pockets, a total of 360 poquets.

Three plots received urea, three received NPK (15-15-15) at a dose of $10 \mathrm{~g}$ per pouch. Three other plots received manure at a dose of $50 \mathrm{~g}$ per pouch and at the end three plots were maintained as controls. The depths of the pouches vary from 2.5 to $5 \mathrm{~cm}$. The spacings between the lines of culture and between the pockets are of $1 \mathrm{~m}$ is a density of 10000 plants per hectare. Seedlings were carried out on July 10, 2018. On a regular basis, the plots were weeded to prevent the invasion of weeds.

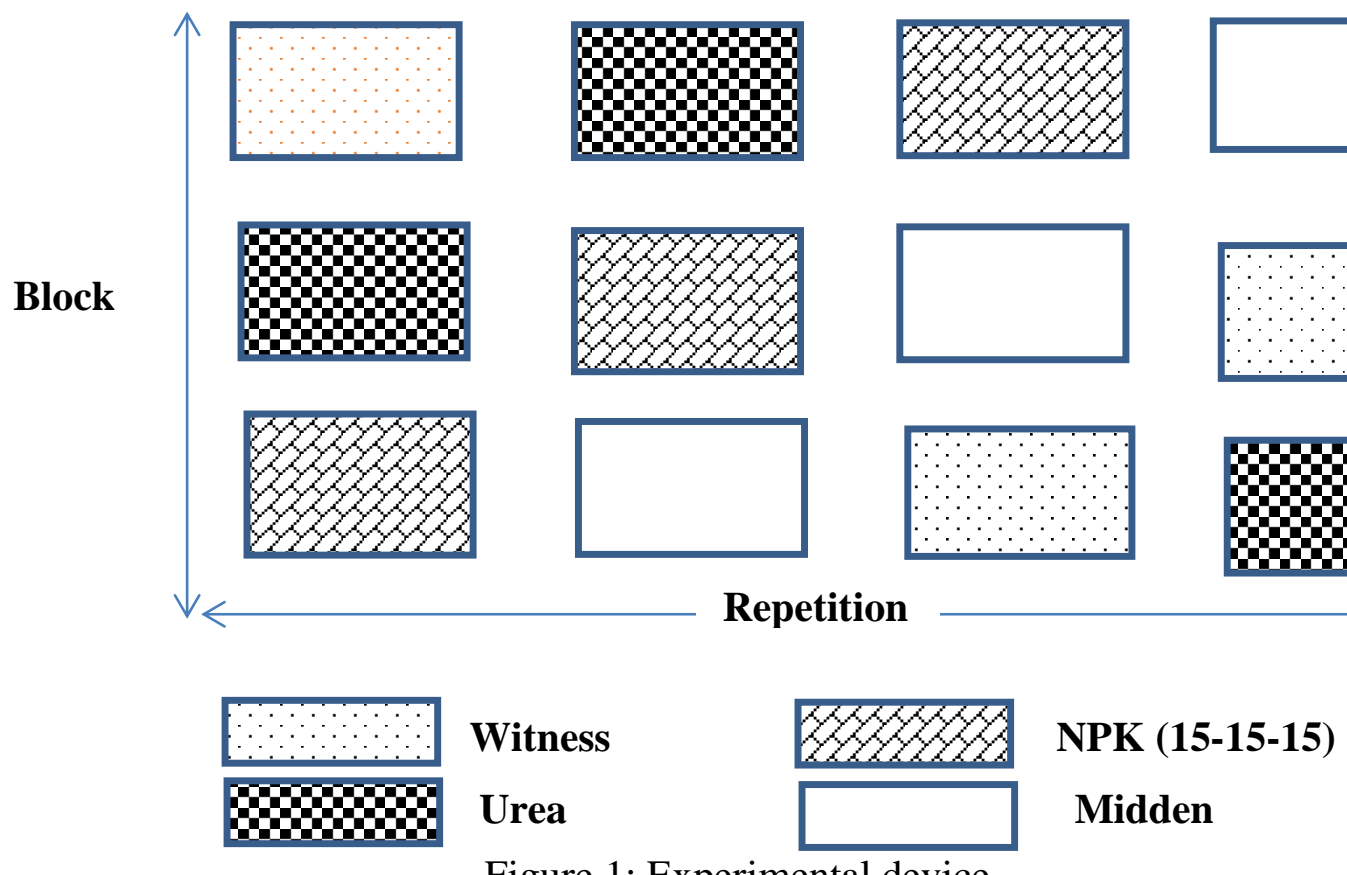

Figure 1: Experimental device

\section{Assessment of Agronomic Parameters}

Three measurements were made during the trial period and involved five plants in each plot. The first measurement was made 15 days after planting, the second, the 30th day after sowing and before fertilization and the third after fertilizer application 45 days after sowing. The parameters evaluated at each observation are the number of branches and leaves per plant, the measurement of plant height and the phenological stage. 
Observations on possible attacks by insects that may have caused certain pathologies have been made. They consist in identifying, throughout the duration of the study, the insect populations present on the species and then evaluate the damage caused by them.

\section{Harvesting and Drying of Biomass}

The biomass harvest was carried out two months after sowing. It consisted in cutting all the plants from the plots from $20 \mathrm{~cm}$ of the collar. The drying of the biomass was done in the shade for 7 days before weighing.

\section{Regeneration Test of Cajanus Cajan}

The Cajanus cajan retake capacity test was also done at the Faculty of Agronomy of Abdou Moumouni University in Niamey. The technique involves cutting about $20 \mathrm{~cm}$ from the neck of one year old plants and observing the fate of the species after cutting. These plants received an organic fertilizer (manure) at a dose of $50 \mathrm{~g}$ per pouch and mineral (urea, 15-15-15) at a dose of $10 \mathrm{~g}$ per pouch.

\section{Ingestibility Test}

The test of ingestibility is carried out on the farm of the Faculty of Agronomy. It consists firstly in harvesting and mixing three kilograms of three different plant species, namely: Gliricida sepium, Leucaena leucocephala, which have been the subject of several studies around the world and Cajanus cajan. Then these quantities are offered to a batch of 6 goats from the Sahel for three successive days. Observations were made on the ingestion of each forage species by the evaluation of relatively unreported quantities.

\section{Data Processing}

Statistical analyzes were made using GenStat 12th edition software to compare the averages of the data collected from the different variables, namely gemination, emergence, plant height, plant leaves, biomass, test $\mathrm{d}$ ingestibility and ability of recovery of the plant after cutting.

\section{Results and Discussions}

\section{Germination of Seeds and Emergence of Seedlings}

Time, duration and seed germination rate and emergence of seedlings are the importants parameters to characterize pigeon pea growth, as shown in Table 1.

Table 1: Time, duration and germination rate and emergence of pigeon pea seeds

\begin{tabular}{|l|l|l|}
\hline Parameters & Germination & Levee (emergence of plants) \\
\hline Delay (Days) & 1 & 7 \\
\hline Duration (Days) & 4 & 10 \\
\hline Rate (\%) & 67,14 & 57,5 \\
\hline
\end{tabular}

Time between placement of seeds in petri dishes and appearance of first radicle (germination time) is 24 hours and the timing of germination duration is 4 days. Seeds germination rate is $67.14 \%$. This low germination rate could be explained by environmental conditions (substrate moisture and ambient temperature) who influence seed germination energy, as Saupe already pointed out in "Plant Physiology" (2006). This rate is below 97-100\% defined by ISTA (International Seed 
Tesing Association) as an adequate germination rate for good seeds, reported by INRAN (1998). Quenum et al. (2016) recorded that germination rates are ranging from $77.5 \%$ to $85 \%$ on various varieties of pigeon pea, despite traditional conditions of storage and conservation of seeds at the producers. Seedling emergence rate was $57.5 \% 15$ days after sowing, and emergence of seedlings was observed 7 days after sowing and the timing of emergence duration is 10 days after sowing. Emergence rate is low compared to that of Jafar (2017), who obtained an average rate of 88.7\% on irrigation. This difference could be due to rotting and abortion of germinated seeds, attack by pathogens or by scarcity of rain during sowing period. According to Louwaars and Marrewitjk (1995), seed vigor depends on genetic makeup, environment, and parent plant nutrition, maturity at harvest, size, weight, and seed density, mechanical integrity, deterioration and aging.

\section{Plant Development \\ Development Height}

Four weeks after emergence, elongation of plants averaged $45.2 \pm 46 \mathrm{~cm}$. Seven (7) weeks after planting and fertilizer application (urea, NPK-15-15-15 and manure), plant heights increased significantly from 45.2 to $100.2 \mathrm{~cm}$. Like heights, the number of twigs and leaves varies seven weeks after sowing (Figure 2).

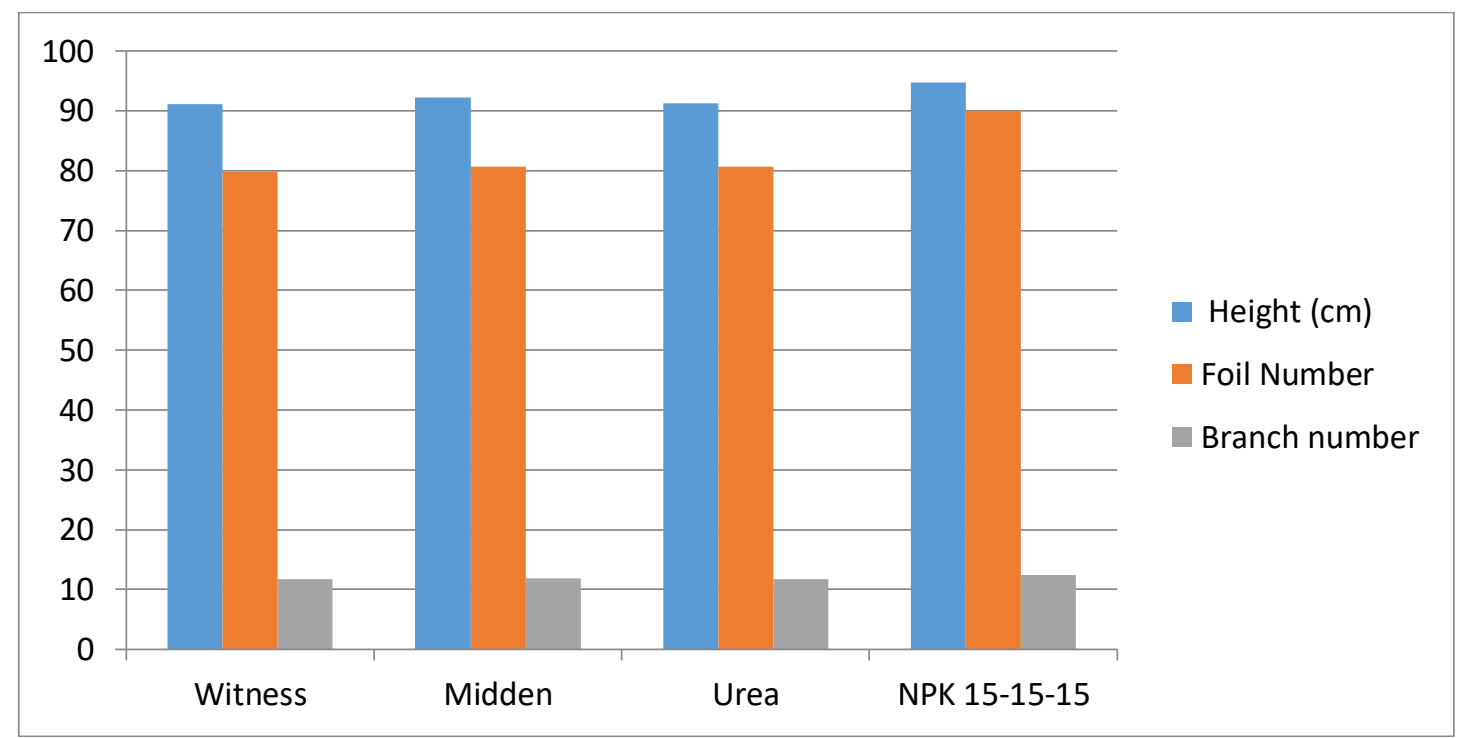

Figure 2: Variation in pruning, twigs, and leaves 7 weeks after sowing.

The analysis of variance of results presented in figure 2 shows that there is no significant difference $(\mathrm{P}>0.5)$ between the different treatments.

\section{Development of Twigs}

The analysis of variance in relation to number of twigs showed no significant difference $(\mathrm{P}>0.5)$ between fertilized plants and control plants. However, plants treated with NPK (15-15-15) seem to be most branched.

\section{Leaf Development}

Figure 2 shows that plants treated with NPK (15-15-15) have more leaves than plants treated with urea, manure, and controls. However, the analysis of variance shows that there is no statistically 
detectable difference between different treatments ( $p>0.5$ ). Follow-up studies of Cajan plants have shown that initial growth of the seedling is particularly slow. Growth becomes fast in the second month. Niyonkuru (2002) has shown that rapid acceleration of pigeon pea plant growth can be explained by the fact that not only are plants in phenological stage of growth but also in considerable amount of nitrogen they fix especially in their young age. The assimilation of this nitrogen contributes a lot to a rapid growth. As for phase where growth is slowed, this could be due to the fact that the plants adapt to the ecological conditions of the environment. Observations made on experimental plots showed that flowering started on 48th day after sowing. Plants fertilized with urea, NPK and manure show no significant growth compared to control plants. These results are consistent with that of Niyonkuru (2002), who notes that the species Cajanus cajan generally does not need manure, whether organic or mineral, except for the crops associated with it. This result is consistent with that obtained by Ido in 2016 which showed that Cajanus cajan flowered between the second and third months with at least $50 \%$ of flowering plants. During the trial and during field observations, no pathology or pest attack was observed at plant level. The explanation is that species Cajanus cajan is only attacked when the plant is fruiting in very humid periods and especially in humid regions.

\section{Production of Aboveground Biomass}

Production of aerial biomass from treated plants is greater than that of control as shown in Figure 3.

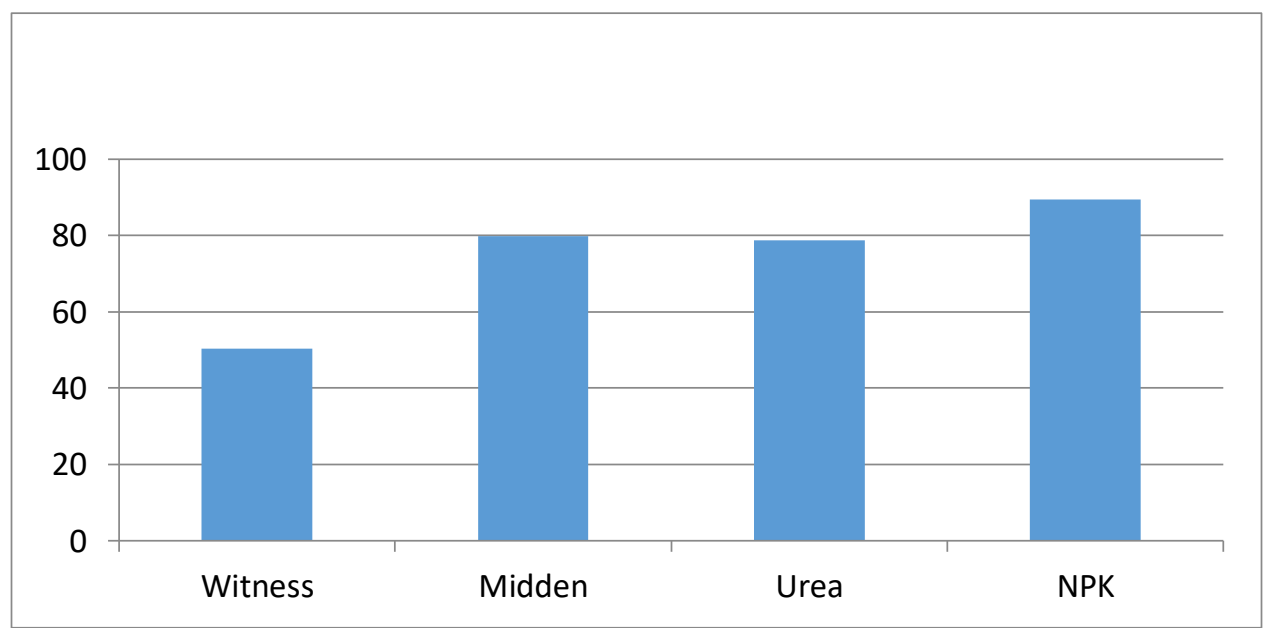

Figure 3: Dry biomass yield (kg / ha)

The plants treated with NPK (15-15-15), manure and urea having respectively 89.42; 79.87; and $78.84 \mathrm{~kg} / \mathrm{ha}$ appear to have highest biomass production 7 weeks after sowing. That of control plants is only $50.46 \mathrm{~kg} / \mathrm{ha}$. Under optimal growing conditions and in pure culture, grain yields of pigeon pea can reach $5000 \mathrm{~kg} / \mathrm{ha}$. However, yields can generally be low (600 kg / ha on average in Africa). These results are different from those of Kouakou (2011) who says that for grazing animals, cuts can be made every two or three months with a productivity of 1.5 to 3.5 tons DM / ha / cut and a nitrogen value of $120 \mathrm{~g}$ MAD / $100 \mathrm{~kg}$ DM. The low yield at first cut can be explained by nature of soil, medium, variety of pigeon pea or by conduct of the test. As for comparison of productions, no significant difference was observed between the biomass yields of fertilized plants and that of control plants. These results are due to fact that pigeon pea plants do not require much fertilizer. 


\section{Recovery Capacity of Cajanus Cajan}

Regarding the recovery of pigeon pea, no sign of degeneration was found on all plants after cutting and fertilizer input. The pigeon pea is a plant that supports the cut. At the first cut, the fresh weight of the forty plants is $12.25 \mathrm{~kg}$ or $3062.5 \mathrm{~kg} / \mathrm{ha}$. Three (3) weeks after cutting, biomass yield varies with treatment (Figure 4).

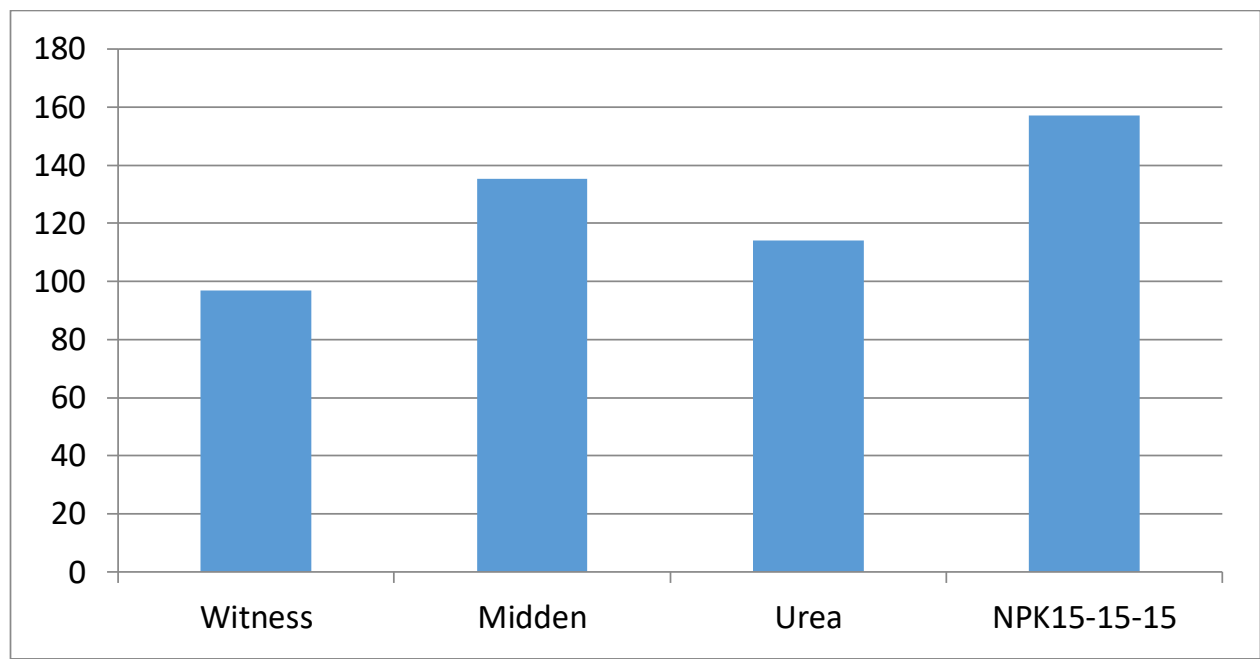

Figure 4: Biomass yield versus treatments three weeks after cutting on 1-year-old plants

The analysis in figure 4 shows that manure, urea, and NPK (15-15-15) treated plants had highest yield while controls had the lowest. The recovery was good for all plants. No difference was observed between fertilized plants and control plants. These results are in agreement with those obtained by Niyonkuru (2002), who notes that pigeon pea plant is harvested gradually with one harvest every two and a half months and provides a well-graded diet in year.

\section{Ingestibility}

With regard to ingestibility, figure 5 present different variations in the consumption of forage species presented to animals.

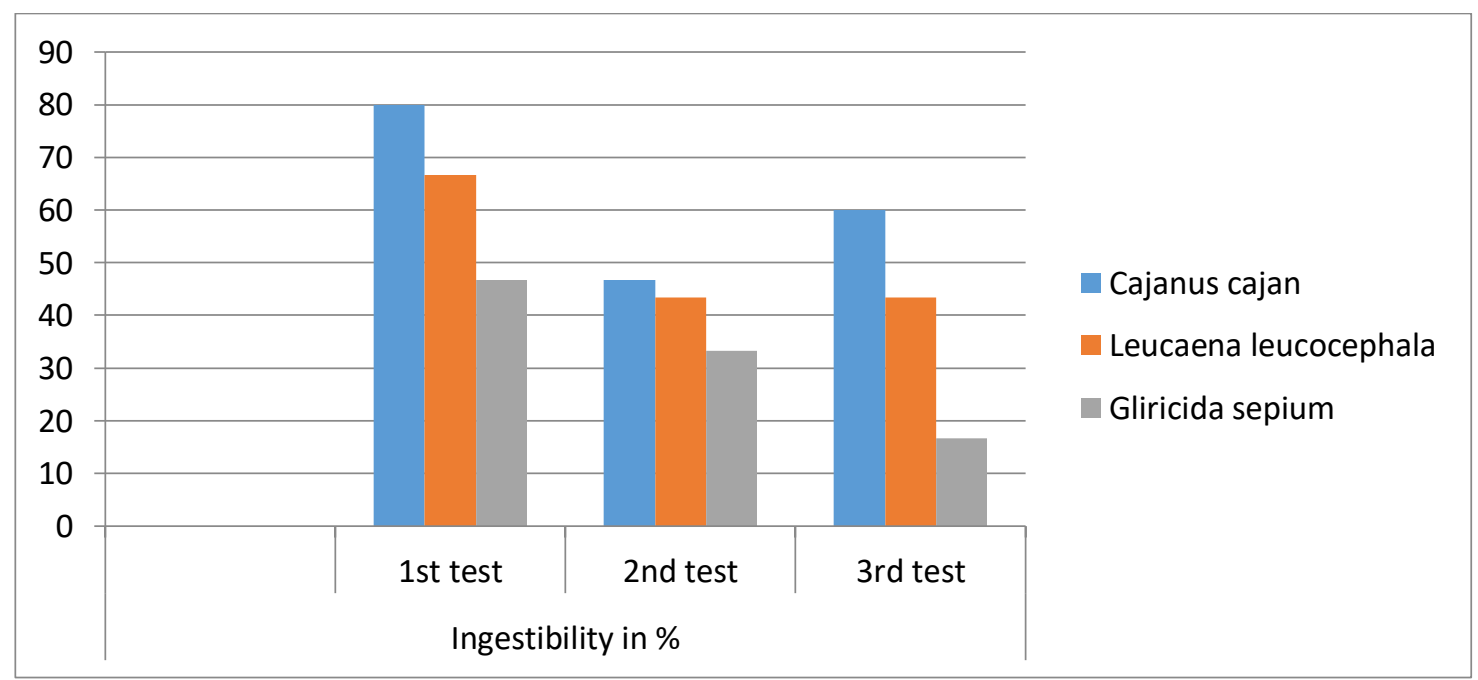

Figure 5: Variation in the consumption of forage species in Sahel goat. 
The analysis in figure 4 shows that pigeon pea foliage is more appreciated by Sahel goat with a palatability of $80 \%$ at first test, $46.66 \%$ at second and $60 \%$ at third test that Leucaena leucocephala has a rate of $66,66 \%$ in the first, $43.33 \%$ in second and third tests. Gliricida sepium is least palatable with a rate of 46.66 on first, 33.33 on second and $16.66 \%$ on last test. This ingestibility test showed that pigeon pea is a better plant than Gliricida sepium and Leucaena leucocephala. This result is found by Kouakou (2011) who states in these terms: "In animal feed, cut foliage is fresh or preserved, a good feed used to feed livestock." The leaves are rich in protein (21-25\% $\mathrm{DM})$ and fiber (30-35\% crude fiber / DM). Note that only tender (non-lignified) stems are palatable.

\section{Conclusion and Recommendations}

Pigeon pea is a species that is under attack in dry areas and produces quality biomass for livestock feed while limiting labor and input investment. The ingestibility test of this species with respect to Gliricida sepium and Leucaena leucocephala has shown that pigeon pea is very popular with animals. Also, the results of evaluation of the production and that of the recovery of the species at one year of installation is encouraging for the establishment of a forage crop. The production of foliar biomass in pigeon pea is not so much related to fertilizer input. This legume forage seems to be able to make profitable the few resources available in the soil. With such production and ease of cultivation, this plant could be used to face the chronic forage deficit in our breeding by the constitution of fodder bank.

\section{References}

[1] Bernard B. Vulnérabilité pastorale et politiques publiques de sécurisation de la mobilité pastorale au sahel. https://www.cairn.info/revue-mondes-en-developpement, 164, 2013, 71-91p.

[2] Cotula L, Vermelen S, Leonard R, Keeley J, Land grab or development opportunity? Agricultural investment and international land deals in Africa, IIED/FAO/IFAD, London/Rome; 2009, 121 p.

[3] Chauveau JP, Colin JP, Jacob PH. LAVIGNE DELVILLE ET P-Y. LE MEUR, Modes d'accès à la terre, marchés fonciers, Gouvernance et politiques foncières en Afrique de l'Ouest, résultats du projet de recherche claims, IIED, Londres, Royaume-Uni, 2006 ; 92 p.

[4] Jouve P. Jeu croisé des dynamiques agraires et foncières en Afrique subsaharienne. Interplays between agrarian and land tenure Dynamics in Africa South of Sahara, Actes du colloque international «Les frontières de la question foncière, At the frontier of land issues», Montpellier, France ; $2006 ; 1-14$.

[5] Cotula L, Hesse C, Sylla O, Thebaud B, Vogt G, Vogt K. Droits fonciers et accès à l'eau au Sahel : Défis et perspectives pour l'agriculture et l'élevage, iied, Londres ; 139; $2006 ; 101 \mathrm{p}$.

[6] Mathieu P, Tabutin D. «Démographie, crise et environnement dans le monde rural africain», In Coussy J. et J.Vallin (dr), Crise et population en Afrique : crises économiques politiques d'ajustement et dynamiques démographiques », les études du CEPED, Paris, n¹3;1996;123171.

[7] Chrysostome C, Xu Bing AN, Bonou M, Delpech P. Variation de l'énergie métabolisable du pois d'angole Cajanus cajan cru et cuit chez le poulet et la pintade. Revue Élev. Méd. vét. Pays trop, 1999; 51 (2) : 131-133.

[8] Siambi M, Oumanga P, Songa W. Statuts and needs of the national pigeon pea research in Kenya.int pigeon pea Newslett $16 ; 1992 ; 36$.

[9] Grâce M., Euloge S., Edwige D. Aspect botanique, profil nutritionnel et implications du pois d'angole (Cajanus cajan) dans le développement communautaire en Afrique subsaharienne. Algerian Journal of Natural Products 5:2, 2009, 469-474. 
[10] Mani M. Caractérisation phénotypique et zootechniques de la chèvre du sahel élevée au Niger. Université Abdou Moumouni. Niamey (Niger) et Université de Dakar (Sénégal) ; 2013.

[11] Jafar A. Culture et appetabilité du pois d'angole dans la région de Tahoua. Mémoire de fin d'études en vue de l'obtention du diplôme de Licence en sciences agronomiques, Université de TahouaNiger ; 2017.

[12] Institut National de la Recherche Agronomique du Niger (INRAN). Atelier ouest Africain sur les semences hybriques du sorgho (Sorghumbicolor) et du mi (Pennisetumglaucum) tenu à Niamey, Niger ; 1998.

[13] Quenum FJB, Djaboutou MC, Houedjissin SS, Sinha MG, Doko R, Cacaï GH, Ahanhanzo C. Diagnostic de la production en appui à l'évaluation de la qualité des semences fermières de pois d'angole (Cajanus cajan (L) Millsp.) au Béni. Bulletin de la Recherche Agronomique du Bénin (BRAB) Numéro 80-Décembre 2016 ; 34-46.

[14] Louwaars NP. Marrewitjk GAM. Seed supply systems in developing countries. Wageningen: 1995, CTA.

[15] Saupe SG. Germination rates and percentages. Plant Physiology, 327: 2006; 278-363.

[16] Niyonkuru DN. La culture du pois cajan. Edition sail collection expériences des fédérations ; Yaoundé Cameroun ; 2002.

[17] Ido EJ, Etude du cycle de développement, production de biomasse, qualité fourragère et effets sur la fertilité du sol de quelques légumineuses fourragères. Mémoire de fin d'étude en vue de l'obtention du diplôme d'ingénieur de vulgarisation agricole. IDR, Université de Bobo-Dioulass ; 2016.

[18] Kouakou FR. Diversité génétique de Rhizobia associé à un champ de pois d'angole mémoire de stage ingénieur. Institut National polytechnique de Yamoussoukro, Cote d'ivoire ; 2011.

\footnotetext{
*Corresponding author.

E-mail address: ousseys@ yahoo.fr
} 